\title{
「かかりつけ薬局」を持つ患者と持たない患者の 視点や意識に関する比較検討
}

\author{
林 誠一郎, ${ }^{*}, a$ 早瀬孝彦, ${ }^{b}$ 池上知子, ${ }^{c}$ 岸野吏志, ${ }^{d}$ 竹内幸一 $a$
}

\section{Comparison of Viewpoints and Awareness between Patients with and without a "Family Pharmacy"}

\author{
Sei-ichiro HAyASHI, ${ }^{*, a}$ Takahiko HAYASE, ${ }^{b}$ Noriko IKegami, ${ }^{c}$ \\ Satoshi KISHINO, ${ }^{d}$ and Koichi TAKEUCHI ${ }^{a}$ \\ aDepartment of Clinical Pharmacology, Meiji Pharmaceutical University, 2-522-1 Noshio, Kiyose, \\ Tokyo 204-8588, Japan, ${ }^{b}$ Pharmaceuticals Sales, Dept. Pharmaceuticals Company, Kyowa Hakko \\ Kogyo Co., Ltd., 1-6-1 Otemachi, Chiyoda-ku, Tokyo 100-8185, Japan, 'Advance Create Inc., \\ Azusa Building 302, 2-5-1 Yotsuya, Shinjuku-ku, Tokyo 160-0004, Japan, and Department \\ of Medication Use Analysis and Clinical Research, Meiji Pharmaceutical \\ University, 2-522-1 Noshio, Kiyose, Tokyo 204-8588, Japan
}

(Received September 28, 2005; Accepted November 16, 2005)

\begin{abstract}
To evaluate differences in viewpoints and awareness between patients with and without a "family pharmacy", we performed a questionnaire survey. The questionnaire consisted of 21 questions including "I often read books and journals about health." and "Patients have the right of being informed of the medical treatment they receive". The degree of applicability was selected among 6 grades ("definitely inapplicable"- "definitely applicable"). The subjects were classified into 3 groups "without a family pharmacy", "with a regular pharmacy for each hospital/clinic" and "with a family pharmacy", and factor analysis was performed. As a result, 5 factors were extracted in each group. However, the order of the 2 nd -4 th factors differed among the 3 groups. Paying attention to these differences, we found that patients "with a family pharmacy" have resolved doubts about or dissatisfaction with medical care to some extent.
\end{abstract}

Key words_— community pharmacy; pharmacist; family pharmacy

\section{は じめに}

医薬分業のもと，薬局では患者毎に「薬歴」を作 成している。これには，その患者の過去から現在に 至る医薬品使用状況，特異体質や副作用経験の有 無, さらには相談のあった事項の要点などを記録し ている，そこで，もし患者がいつも利用する薬局を 1 力所の「かかりつけ薬局」に決めておけば, 薬歴 には多くの情報が蓄積されることになる.

患者について多くの情報が得られれば，薬剂師は きめ細かな服薬説明を行ったり，心配・不安の相談 に対して具体的に応えることができる. 大衆薬や特

$a$ 明治薬科大学臨床薬理学教室, $b$ 協和発酵工業株式会 社医薬営業統括部，cアドバンス・クリエイト株式会社,

$d$ 明治薬科大学薬剂情報解析学教室

連絡先：日本薬剂師会中央薬事情報センター（テ160-

8389 東京都新宿区四谷 3-3-1 富士・国保連ビル 7F)

*e-mail: s.hayashi@dream.com
定保健用食品等の使用に関しても，より的確な助言 を行うことができる．また，患者が複数の医療機関 を受診している場合には，薬の重複や相互作用を防 止することが可能である。 さらに，患者が病院に入 退院する場合には，入院時に「持参薬」等の情報を 病院薬剂部に伝えたり，退院時に発行される「退院 時服薬指導」の説明書をより有効に利用することも 可能である.

以上の通り, 医薬品の適正使用等の観点から, 患 者には「かかりつけ薬局」を持つことが望まれる. しかし，日本大衆薬工業協会の調査 ${ }^{1)}$ によれば, 「かかりつけ薬局」を「持っている」とした人は $25.2 \%$ ，また，健康保険組合連合会の調査 ${ }^{2}$ によれ ば，「かかりつけ薬局」を「決めている」とした人 は44.1\%であった. したがって，「かかりつけ薬局」 は，社会に十分に浸透しているとは言い難い.

このような中，薬局関係者は患者が「かかりつけ 
薬局」を持つための対策を考える必要がある，糟谷 らは，患者が「かかりつけ薬局」を決定する要因に ついて検討を行い，決定に影響を与えている変量と して「保険薬局における秘密やプライバシーの秘守」 「医薬分業に対する満足」「年齢」を挙げている. ${ }^{3)}$ また，印南らはプライバシー保護が，薬剤師への信 頼や「かかりつけ薬局」の決定に大きな影響を与え ていることを指摘している. ${ }^{4}$

しかし，患者が薬局を選ぶ理由には，プライバ シー保護など薬局側が提供するサービスのみなら ず，患者自身の考え方も関係があると思われた。 そ こで，われわれは「かかりつけ薬局」を持つ患者と 持たない患者とでは，視点や意識にどのような違い があるのかを知るためにアンケート調査を行った.

\section{方法}

1. 調査の設問と方法 設問では，まず回答者 の年齢・性別などのほか, 最近 1 年間において薬局 で調剤を受けた回数について質問した。選択肢は $\lceil 1$ 回も行っていない」「年 1〜3 回ぐらい」「年 4〜 10 回ぐらい」「年 12 回前後（月に 1 回程度）」「そ れよりも多い」の 5 肢とした。

ついで, 回答者が病院や診療所を受診し，院外処 方せんを受け取った場合に，行く薬局を決めている か否かを質問し，「特に決めていない」「病院・診療 所ごとに行く薬局をだいたい決めている」「どこの 病院・診療所にかかろうとも，調剂を受ける薬局 は，だいたい 1 カ所の『かかりつけ薬局』に統一し ている」の 3 肢から 1 つを選択してもらつた。本論 文では，以降，これらを順に「決めていない群」 「病院・診療所ごと群」かかりつけ薬局群」とする.

さらに，回答者の健康に対する関心，医療に対す る考え方等について, Table 1 に示す $\mathrm{A}-\mathrm{U}$ の 21 設問を用意した．回答者には，設問ごとに「全くあ てはまらない」一「よくあてはまる」の 6 肢から 1 つを選択してもらつた。

調査は，2003 年 3-5 月において，協力の得られ た薬局の店頭で不特定の患者に調査票を配付し，回 答は郵送にて回収する方法（調査方法 1)，及び協 和発酵工業株式会社（以降，協和発酵とする）の社 員・家族に調査票を配付し，回答は無記名にて事業 所に設置した回収箱で回収する方法（調查方法 2) とした.
なお，調査方法 2 では同社の医薬品部門は対象外 とし，食品，酒類，化学品等を扱う施設の社員・家 族に対してのみ調査票を配付し回収した．対象とし た施設（都道府県名；事業内容）は，具体的に札幌 支店 (北海道 ; 食品, 酒類, 化学品), 土浦工場 （茨城県；食品, 総務), 本社（東京都；食品, 酒 類, 総務), 東京研究所 (東京都; 化学品, バイ 才)，堺工場（大阪府；食品，総務），宇部工場（山 口県; 化学品, 総務), 防府工場（山口県; 酒精, 化学品, 総務), 九州支社（福岡県；食品，酒類） の 6 都道府県 8 施設とした.

2. 解析方法 解析対象は, 調査方法 1 と同 2 の回答を合わせたのち, 年齢, 性別, 居住地（又は 施設）の都道府県名が判明しているものを抽出し, さらに(1)年齢 20 歳以上，(2)最近 1 年間において薬 局で調剂を受けた回数が 4 回以上，(3)院外処方せん を受け取った場合に，行く薬局を決めているか否か の質問に回答している，(4)Table 1 の A-U の全設 問に回答している，の条件をすべて満たす回答とし た。なお，(1)については，低年齢であると自己の意 志で薬局を選択していない可能性が高いと考えたこ とによる，また(2)につては，日ごろあまり薬局を 利用しない人では「かかりつけ薬局」を意識するこ とが少ないと考えたことによる.

解析は, 患者を「決めていない群」「病院・診療 所ごと群」「かかりつけ薬局群」の 3 群に分けて行 つた。 Table 1 の各設問の回答結果について，「全 くあてはまらない」 1 点一「よくあてはまる」 6 点 を割り当てて, 設問ごとに加重平均值を計算した。 集計結果の群間比較では，Kruskal-Wallis 検定を用 いた.

さらに，この点数割り当てを用いて各群について 因子分析を行った。分析には SAS ver 8.2 (SAS Institute Inc.）を用い，因子の抽出方法は主因子法, 因子軸の回転方法はバリマックス法とした。因子数 の決定は，固有值（Eigenvalue）の減衰状況を基本 としたが，各因子を実際によく説明できることも考 慮した。また，解析過程で因子負荷量が 0.40 未満 となった設問は，当該因子と関連が薄いと判断して 除外し，再度，因子分析を行った。

なお，調査方法 1 と同 2 の回答を合わせて解析す ることの問題を検討するために，方法別にも，解析 対象者の内訳と各設問の加重平均值を計算した. 
Table 1. Results of 21 Questions about Patient's Points of View

\begin{tabular}{|c|c|c|c|c|c|c|}
\hline & 設 & $\begin{array}{l}\text { 決めて } \\
\text { いない群 } \\
(n=351)\end{array}$ & $\begin{array}{c}\text { 病院・診療所 } \\
\text { ( } \\
(n=1114)\end{array}$ & $\begin{array}{l}\text { かかりつけ } \\
\text { 薬局群 } \\
(n=382)\end{array}$ & $(n=1847)$ & $\begin{array}{c}\text { Kruskal-Wallis } \\
\text { test } \\
\quad(p<0.001)\end{array}$ \\
\hline A. & 健康に関する本や雑誌をよく読む方である & 3.32 & $\underline{3.72}$ & 3.69 & 3.64 & $\bigcirc$ \\
\hline & $\begin{array}{l}\text { 寊分の健康のために, 日頃, 心がけていることが } \\
\text { ある }\end{array}$ & 3.91 & $\overline{4.24}$ & $\underline{4.38}$ & 4.20 & 0 \\
\hline C. & $\begin{array}{l}\text { 薬の副作用に関する新聞記事やニュースに興味が } \\
\text { ある }\end{array}$ & 4.24 & $\underline{4.72}$ & 4.69 & 4.62 & $\bigcirc$ \\
\hline & 健康食品に興味がある & 3.55 & $\underline{3.75}$ & 3.64 & 3.69 & N.S. \\
\hline & 医師の治療方針に対して，疑問をもつことがある & $\underline{3.62}$ & 3.54 & 3.33 & 3.51 & N.S. \\
\hline & $\begin{array}{l}\text { 治療を受ける際, 患者にはその内容について知る } \\
\text { 権利がある }\end{array}$ & $\overline{5.34}$ & $\underline{5.52}$ & 5.43 & 5.47 & N.S. \\
\hline & $\begin{array}{l}\text { 医療関係者に, 自分の要望を聞いてほしいと思う } \\
\text { こがある }\end{array}$ & 4.48 & $\underline{4.64}$ & 4.46 & 4.57 & N.S. \\
\hline & $\begin{array}{l}\text { 治療を受ける際, 担当医からの説明だけでなく, } \\
\text { 第者の意見も聞いていた }\end{array}$ & 3.93 & $\underline{4.10}$ & 3.91 & 4.03 & N.S. \\
\hline & 医薬分業は，それなりに意義があると思う & 3.89 & 4.27 & $\underline{4.51}$ & 4.25 & $\bigcirc$ \\
\hline & 薬局薬剤師に親しみがもてる & 3.37 & 4.03 & $\underline{4.77}$ & 4.05 & $\bigcirc$ \\
\hline & 薬局薬剤師の仕事ぶりは評価できる & 3.72 & 4.30 & $\overline{4.86}$ & 4.30 & $\bigcirc$ \\
\hline & $\begin{array}{l}\text { 薬局薬剤師に, 自分の病名や他に飲んでいる薬な } \\
\text { こを話すと抗はな }\end{array}$ & 4.17 & 4.60 & $\underline{4.87}$ & 4.57 & O \\
\hline & 薬局薬剤師のアドバイスに耳を傾ける方である & 4.34 & 4.80 & $\underline{5.03}$ & 4.76 & O \\
\hline & $\begin{array}{l}\text { 薬剤師による「薬のチェック」や「薬の説明」の } \\
\text { 作業に対してお紫を払つもいい }\end{array}$ & 2.82 & 2.97 & $\underline{3.36}$ & 3.02 & O \\
\hline & 薬局薬剤師の話は大切だと思って聞く気になれる & 4.05 & 4.55 & $\underline{4.82}$ & 4.51 & 0 \\
\hline & 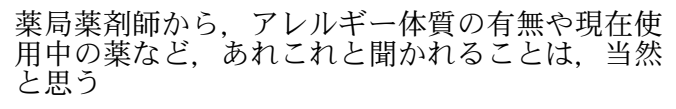 & 4.78 & $\underline{5.11}$ & 5.07 & 5.04 & 0 \\
\hline & 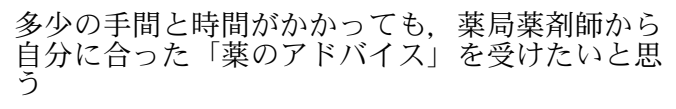 & 4.26 & 4.55 & $\underline{4.77}$ & 4.54 & 0 \\
\hline & $\begin{array}{l}\text { 自分が「これ!方である } \\
\text { わ思ったことは, 最後までこだ }\end{array}$ & 3.96 & 4.16 & $\underline{4.28}$ & 4.15 & N.S. \\
\hline & $\begin{array}{l}\text { レストランや美容院・理髪店などは「行きつけ」 } \\
\text { の店が }\end{array}$ & 4.56 & 4.87 & $\underline{4.93}$ & 4.82 & 0 \\
\hline & $\begin{array}{l}\text { ファーストフードなどよりも，店員と世間話がで } \\
\text { きる飲食店の方が好きだ }\end{array}$ & 3.30 & 3.56 & 3.89 & 3.58 & 0 \\
\hline & $\begin{array}{l}\text { 恏きなスポーツ選手やタレン゙ートには, 心情的に身 } \\
\text { 内意識が強くなる方であ }\end{array}$ & 3.09 & 3.30 & $\underline{3.42}$ & 3.28 & N.S. \\
\hline
\end{tabular}

注：表中の数值は, 各設問の回答結果について,「全くあてはまらない」 1 点,「あまりあてはまらない」 2 点,「どちらかといえばあてはまらない」 3 点, 「どちらかといえばあてはまる」4 点,「ややあてはまる」5 点,「よくあてはまる」6点, として計算した加重平均值. 表中のアンダーラインは, 3 群間で 最も高值のもの. Kruskal-Wallis test は，「決めていない群」「病院・診療所ごと群」「かかりつけ薬局群」の 3 群間での検定結果． ( 有意差なし).

\section{結果}

1. 全体の集計結果＼cjkstart調査方法 1 では, 29 都 道府県の 174 薬局を通して 4210 部の調査票を配付 し，1906 部の回答を得た（回収率 45.3\%）。また, 調査方法 2 では, 協和発酵の 6 都道府県 8 施設に 3190 部の調査票を配付し，2246 部の回答を得た (回収率 70.4\% )。これより，全体としては 7400 部 の調査票について 4152 部の回答を得た（回収率 $56.1 \%)$.

調査方法 2 の詳細は, 施設（配付部数/回収部数）
毎に，札幌支店 $(450 / 303)$ ，土浦工場 $(270 / 187)$, 本社 $(610 / 467)$, 東京研究所 $(210 / 148)$, 堺工場 (150/95), 宇部工場 (450/329), 防府工場 (670/ 445), 九州支社 $(380 / 272)$ であった.

回答者の年齢は，30 未満 $14.3 \% ， 30$ 代 $25.4 \%$, 40 代 $18.8 \% ， 50$ 代 $18.6 \% ， 60$ 代 $10.2 \% ， 70$ 代以 上 $12.7 \%$ ，また，性別は男 $52.8 \%$ ，女 $47.2 \%$ 。さ らに最近 1 年間において薬局で調剂を受けた回数 は，「1 回も行っていない」 $14.9 \%, 「$ 年 1 3 回ぐ らい」 $24.8 \%, 「$ 年 4〜10 回ぐらい」21.4\%,「年 12 回前後（月に 1 回程度)」 $16.4 \%$ 「「れよりも多い」 
22.5\%であつた。

\section{2. 解析対象の集計結果解析条件を満たし} た患者は 1847 人で, 内訳は Table 2 の通り，「決め ていない群」 351 人 $(19.0 \%)$, 「病院・診療所ごと 群」 1114 人 $(60.3 \%)$,「かかりつけ薬局群」 382 人 （20.7\%）となった。平均年齢は，「かかりつけ薬局 群」が 54.5 歳で最も高く，糟谷ら ${ }^{3)}$ と同様の結果 が得られた。また，調查方法別の集計では，調査方 法 1 の方が同 2 よりも，「かかりつけ薬局群」の人 数比が高かった.

Table 1 の各設問の回答結果について，「全くあ てはまらない」 1 点一「よくあてはまる」6 点を割 り当てた場合の, 各群及び全体の加重平均值は, 同 Table に記載の通りとなった．全体の集計では，設 問 $\mathrm{F}$ （治療を受ける際，患者にはその内容について 知る権利がある： 5.47), 設問 $\mathrm{P}($ 薬局薬剤師から, アレルギー体質の有無や現在使用中の薬など，あれ これと聞かれることは，当然と思う：5.04）などが 高值となり，患者はこれらに関して比較的「あては まる」と考える傾向が見られた。一方，設問 $\mathrm{N}$ (薬剤師による「薬のチェック」や「薬の説明」の 作業に対してお金を払つてもいい：3.02），設問 U （好きなスポーツ選手やタレントには，心情的に身 内意識が強くなる方である：3.28）などが低值とな り，患者はこれらに関して比較的「あてはまらない」 と考える傾向が見られた。

各群間の比較では，21 設問中 13 設問で「かかり つけ薬局群」の加重平均值が最も高くなり, そのう ち 11 設問については 3 群間で有意差が見られた

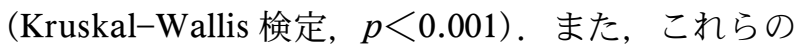
11 設問についてはすべて 2 番目が「病院・診療所
ごと群」, 3 番目が「決めていない群」の順となつた.

調查方法別の集計結果は Table 3 の通り，全般的 に調查方法 1 の方が同 2 よりも高值であった．設問 $\mathrm{J}$ （薬局薬剤師に親しみがもてる）や設問 K（薬局 薬剂師の仕事ぶりは評価できる）などに着目する と, 調査方法 1 の患者の方が薬局薬剤師により好意 的である傾向が見られた。

3. 因子分析の結果各群の因子分析を行った 結果，いずれにおいても5 因子が抽出されると判断 し，バリマックス回転後の因子負荷量と因子寄与率 は Table 4-6の通りとなった.

「決めていない群」（Table 4）における第 1 因子 は，薬剤師の服薬指導や薬歴管理に関する設問内容 であることから「薬剤師業務の理解」と命名した. 第 2 因子は，医療に対する要望や意見に関する設問 内容であり，これらを肯定する患者の背景を考えて 「懐疑・不満」と命名した。第 3 因子は, 健康につ いての情報収集等に関する設問内容であることから 「健康への関心」と命名した。第 4 因子は，薬剤師 に対する親しみや薬剤師に代価を支払うことに関す る設問内容であることから「薬局薬剂師への評価」 と命名した。第 5 因子は，人や店などに対する関 心，こだわりについての設問内容であることから 「人や店への愛着心」と命名した．他の群について も，各因子と相関の高かった設問はおおむね同じ構 成となったので，因子の命名も同様とした。

第 1 因子「薬剂師業務の理解」及び第 5 因子「人 や店への愛着心」は，どの群でも同じであった。し かし，第 2 因子は，「決めていない群」(Table 4) では「懐疑・不満」,「病院・診療所ごと群」（Table 5）では「薬局薬剤師への評価」，また，「かかりつ

Table 2. Profiles of Patients as Subjects of Analysis

\begin{tabular}{|c|c|c|c|c|}
\hline & 決めていない群 & 病院・診療所ごと群 & かかりつけ薬局群 & 計 \\
\hline 患者数 & $351(19.0 \%)$ & $1114(60.3 \%)$ & $382(20.7 \%)$ & $1847(100 \%)$ \\
\hline 平均年齢 & 43.6 歳 & 49.0 歳 & 54.5 歳 & 49.1 歳 \\
\hline \multicolumn{5}{|l|}{ 性別内訳 } \\
\hline 男性 & 198 & 484 & 175 & 857 \\
\hline 女性 & 153 & 630 & 207 & 990 \\
\hline \multicolumn{5}{|c|}{ 調査方法別内訳 } \\
\hline 調査方法 1 & $125(11.4 \%)$ & $646(59.1 \%)$ & $323(29.5 \%)$ & $1094(100 \%)$ \\
\hline 調査方法 2 & $226(30.0 \%)$ & $468(62.2 \%)$ & $59(7.8 \%)$ & $753(100 \%)$ \\
\hline
\end{tabular}

注：平均年齢の項以外の数值は人数.なお, 平均年齢については, 「決めていない群」「病院・診療所ごと群」「かかりつけ薬局 群」の 3 群間で有意差が認められた. (Kruskal-Wallis test, $p<0.001$ ). 
Table 3. Comparison of the Results of Survey between the Two Survey Methods

\begin{tabular}{|c|c|c|c|}
\hline & 問 & $\begin{array}{l}\text { 調査方法 } 1 \\
(n=1094)\end{array}$ & $\begin{array}{l}\text { 調査方法 } 2 \\
(n=753)\end{array}$ \\
\hline & 健康に関する本や雑誌をよく読む方である & 3.79 & 3.42 \\
\hline & 自分の健康のために, 日頃, 心がけていることがある & $\overline{4.39}$ & 3.93 \\
\hline & 薬の副作用に関する新聞記事やニュースに興味がある & $\overline{4.73}$ & 4.47 \\
\hline & 健康食品に興味がある & 3.74 & 3.63 \\
\hline & 医師の治療方針に対して，疑問をもつことがある & $\overline{3.39}$ & 3.69 \\
\hline & 治療を受ける際, 患者にはその内容について知る権利がある & 5.46 & $\overline{5.48}$ \\
\hline & 医療関係者に, 自分の要望を聞いてほしいと思うことがある & 4.59 & $\overline{4.55}$ \\
\hline & 治療を受ける際, 担当医からの説明だけでなく, 第三者の意見も聞いておきたい & 4.05 & 3.99 \\
\hline & 医薬分業は，それなりに意義があると思う & $\overline{4.42}$ & 3.99 \\
\hline & 薬局薬剤師に親しみがもてる & $\overline{4.46}$ & 3.46 \\
\hline & 薬局薬剤師の仕事ぶりは評価できる & 4.69 & 3.74 \\
\hline & 薬局薬剂師に, 自分の病名や他に飲んでいる薬などを話すことに抵抗はない & 4.77 & 4.29 \\
\hline & 薬局薬剤師のアドバイスに耳を傾ける方である & $\overline{4.96}$ & 4.46 \\
\hline & 薬剤師による「薬のチェック」や「薬の説明」の作業に対してお金を払つてもいい & 3.18 & 2.78 \\
\hline & 薬局薬剤師の話は大切だと思って聞く気になれる & 4.78 & 4.12 \\
\hline & $\begin{array}{l}\text { 薬局薬剤師から，アレルギー体質の有無や現在使用中の薬など，あれこれと聞かれることは， } \\
\text { 当然年か }\end{array}$ & $\overline{5.10}$ & 4.95 \\
\hline & 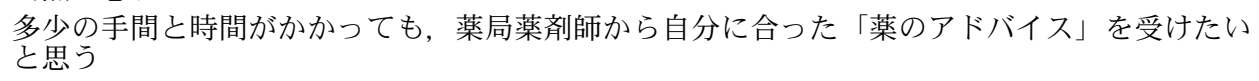 & 4.72 & 4.29 \\
\hline & 自分が「これ!」と思ったことは, 最後までこだわる方である & 4.28 & 3.95 \\
\hline & レストランや美容院・理髪店などは「行きつけ」の店が多い & $\overline{4.97}$ & 4.60 \\
\hline & ファーストフードなどよりも, 店員と世間話ができる飲食店の方が好きだ & 3.72 & 3.38 \\
\hline & 好きなスポーツ選手やタレントには, 心情的に身内意識が強くなる方である & $\overline{3.28}$ & 3.28 \\
\hline
\end{tabular}

注：調査方法 1 は, 協力の得られた薬局の店頭で不特定の患者に調查票を配付し, 回答は郵送にて回収した. 調査方法 2 は, 協和発酵の社員・家族（医 薬品部門は除外）に調查票を配付し，回答は無記名にて，事業所に設置した回収箱で回収した. なお，表中の数值は，Table 1 と同様の点数割り当てによ り計算した加重平均值. アンダーラインは，2つの方法間で高值のもの.

Table 4. Results of Factor Analysis in the Group "without a Family Pharmacy”

\begin{tabular}{|c|c|}
\hline 因子 と 設 問 & 因子負荷量 \\
\hline \multicolumn{2}{|l|}{ 第 1 因子：薬剂師業務の理解（因子寄与率：14.58\%） } \\
\hline M. 薬局薬剤師のアドバイスに耳を傾ける方である & 0.77 \\
\hline P. 薬局薬剤師から, アレルギー体質の有無や現在使用中の薬など， あれこれと聞かれることは，当然と思う & 0.72 \\
\hline O． 薬局薬剤師の話は大切だと思って聞く気になれる & 0.67 \\
\hline Q. 多少の手間と時間がかかっても，薬局薬剤師から自分に合った「薬のアドバイス」を受けたいと思う & 0.66 \\
\hline L. 薬局薬剤師に, 自分の病名や他に飲んでいる薬などを話すことに抵抗はない & 0.55 \\
\hline \multicolumn{2}{|l|}{ 第 2 因子：懐疑・不満（因子寄与率：9.76\%） } \\
\hline G. 医療関係者に，自分の要望を聞いてほしいと思うことがある & 0.70 \\
\hline H． 治療を受ける際，担当医からの説明だけでなく，第三者の意見も聞いておきたい & 0.69 \\
\hline E． 医師の治療方針に対して, 疑問をもつことがある & 0.58 \\
\hline F． 治療を受ける際，患者にはその内容について知る権利がある & 0.47 \\
\hline \multicolumn{2}{|l|}{ 第 3 因子：健康への関心（因子寄与率：9.25\%） } \\
\hline A． 健康に関する本や雑誌をよく読む方である & 0.66 \\
\hline D. 健康食品に興味がある & 0.63 \\
\hline B． 自分の健康のために, 日頃, 心がけていることがある & 0.62 \\
\hline C． 薬の副作用に関する新聞記事やニュースに興味がある & 0.58 \\
\hline \multicolumn{2}{|l|}{ 第 4 因子：薬局薬剂師への評価（因子寄与率：7.97\%） } \\
\hline J ． 薬局薬剤師に親しみがもてる & 0.76 \\
\hline K． 薬局薬剤師の仕事ぶりは評価できる & 0.68 \\
\hline N. 薬剤師による「薬のチェック」や「薬の説明」の作業に対してお金を払つてもいい & 0.41 \\
\hline \multicolumn{2}{|l|}{ 第 5 因子：人や店への愛着心（因子寄与率：5.43\%） } \\
\hline R. 自分が「これ !」と思ったことは, 最後までこだわる方である & 0.56 \\
\hline S．レストランや美容院・理髪店などは「行きつけ」の店が多い & 0.54 \\
\hline T. ファーストフードなどよりも, 店員と世間話ができる飲食店の方が好きだ & 0.40 \\
\hline
\end{tabular}

注 : $n=351$. 固有值（Eigenvalue）：第 1 因子 4.57 ，第 2 因子 1.91 ，第 3 因子 1.32 ，第 4 因子 0.59 ，第 5 因子 0.53 . 
Table 5. Results of Factor Analysis in the Group "with a Regular Pharmacy for each Hospital/Clinic"

\begin{tabular}{|c|c|}
\hline 因子 と 設 問 & 因子負荷量 \\
\hline \multicolumn{2}{|l|}{ 第 1 因子：薬剤師業務の理解（因子寄与率：15.14\%） } \\
\hline M. 薬局薬剤師のアドバイスに耳を傾ける方である & 0.74 \\
\hline O． 薬局薬剤師の話は大切だと思って聞く気になれる & 0.74 \\
\hline P. 薬局薬剤師から，アレルギー体質の有無や現在使用中の薬など，あれこれと聞かれることは，当然と思う & 0.67 \\
\hline Q．多少の手間と時間がかかっても，薬局薬剂師から自分に合った「薬のアドバイス」を受けたいと思う & 0.65 \\
\hline L．薬局薬剤師に，自分の病名や他に飲んでいる薬などを話すことに抵抗はない & 0.57 \\
\hline \multicolumn{2}{|l|}{ 第 2 因子 : 薬局薬剤師への評価（因子寄与率 : 9.29\%） } \\
\hline J ． 薬局薬剤師に親しみがもてる & 0.75 \\
\hline K． 薬局薬剤師の仕事ぶりは評価できる & 0.73 \\
\hline I ． 医薬分業は，それなりに意義があると思う & 0.44 \\
\hline \multicolumn{2}{|l|}{ 第 3 因子：健康への関心（因子寄与率：8.16\%） } \\
\hline A． 健康に関する本や雑誌をよく読む方である & 0.64 \\
\hline B. 自分の健康のために, 日頃, 心がけていることがある & 0.59 \\
\hline C． 薬の副作用に関する新聞記事やニュースに興味がある & 0.53 \\
\hline D. 健康食品に興味がある & 0.52 \\
\hline \multicolumn{2}{|l|}{ 第 4 因子：懐疑・不満（因子寄与率：7.85\%） } \\
\hline G. 医療関係者に, 自分の要望を聞いてほしいと思うことがある & 0.66 \\
\hline E．医師の治療方針に対して，疑問をもつことがある & 0.53 \\
\hline H. 治療を受ける際, 担当医からの説明だけでなく, 第三者の意見も聞いておきたい & 0.52 \\
\hline F． 治療を受ける際, 患者にはその内容について知る権利がある & 0.50 \\
\hline \multicolumn{2}{|l|}{ 第 5 因子：人や店への愛着心（因子寄与率：3.09\%） } \\
\hline T. ファーストフードなどよりも, 店員と世間話ができる飲食店の方が好きだ & 0.43 \\
\hline U． 好きなスポーツ選手やタレントには, 心情的に身内意識が強くなる方である & 0.42 \\
\hline
\end{tabular}

注 : $n=1114$. 固有值（Eigenvalue）: 第 1 因子 4.36 , 第 2 因子 1.50 , 第 3 因子 0.97 , 第 4 因子 0.61 , 第 5 因子 0.39 .

Table 6. Results of Factor Analysis in the Group "with a Family Pharmacy”

因子と設問

第 1 因子 : 薬剂師業務の理解（因子寄与率：15.47\%)

O. 薬局薬剂師の話は大切だと思って聞く気になれる

0.75

P . 薬局薬剤師から，アレルギー体質の有無や現在使用中の薬など，あれこれと聞かれることは，当然と思う

M. 薬局薬剂師のアドバイスに耳を傾ける方である

0.69

Q. 多少の手間と時間がかかっても，薬局薬剤師から自分に合った「薬のアドバイス」を受けたいと思う

0.64

L ．薬局薬剂師に，自分の病名や他に飲んでいる薬などを話すことに抵抗はない

0.53

第 2 因子：健康への関心（因子寄与率：7.85\%)

C. 薬の副作用に関する新聞記事やニュースに興味がある

0.61

B．自分の健康のために，日頃，心がけていることがある

0.56

A. 健康に関する本や雑誌をよく読む方である

0.54

F . 治療を受ける際，患者にはその内容について知る権利がある

第 3 因子 : 薬局薬剤師への評価（因子寄与率：7.82\%）

$\mathrm{J}$. 薬局薬剤師に親しみがもてる

0.68

$\mathrm{K}$. 薬局薬剤師の仕事ぶりは評価できる

I . 医薬分業は，それなりに意義があると思う

第 4 因子：懐疑・不満（因子寄与率：7.13\%)

H. 治療を受ける際，担当医からの説明だけでなく，第三者の意見も聞いておきたい

G. 医療関係者に，自分の要望を聞いてほしいと思うことがある

E．医師の治療方針に対して，疑問をもつことがある

第 5 因子：人や店への愛着心（因子寄与率： $5.44 \%$ )

T．ファーストフードなどよりも，店員と世間話ができる飲食店の方が好きだ

U． 好きなスポーツ選手やタレントには，心情的に身内意識が強くなる方である

S ．レストランや美容院・理髪店などは「行きつけ」の店が多い 
け薬局群」(Table 6) では「健康への関心」となり, 各群で異なった。また，第 3 因子，第 4 因子につい ても各群間で一部の違いが見られた.

\section{考察}

1. 調査における「かかりつけ薬局」 現在, 「かかりつけ薬局」の明確な定義はない，複数の報 告5,6)では，調剤と大衆薬等の購入のいずれについ ても，同じ薬局を利用するものを「かかりつけ薬局」 として調査を実施している。しかし，「かかりつけ 薬局」の機能は, この 2 要素に留まらず, 薬に関す る心配・不安の相談, 健康相談や医師への受診勧 告, 禁煙・節酒の指導, さらには在宅医療への参加 など多岐に渡るであろう。本来，「かかりつけ薬局」 とは，患者自身が自己のニーズと意志で決めるもの であり，仮に 1 力所の医療機関しか受診していない 場合などであっても存在し得る.

今回は，調査において，患者の医療に対する考え 方や健康への関心などに着目することとしたので, 調剂に関して，いつも同じ薬局を利用しているか否 かを基準として，「かかりつけ薬局」の有無を判断 することとした。したがって，今後は大衆薬等の購 入など，他の視点でも検討する必要がある.

一方，健康保険組合連合会の調査 ${ }^{2)}$ によれば，患 者は医療機関の近くにある薬局をいつも利用してい ることで，その薬局を「かかりつけ薬局」と見なし ている可能性のあることが指摘されている。このよ うなケースは，本来の「かかりつけ薬局」と区別す る必要がある。そこで，今回の調査では，回答の選 択肢を「特に決めていない」「病院・診療所ごとに 行く薬局をだいたい決めている」「どこの病院・診 療所にかかろうとも，調剤を受ける薬局は，だいた い 1 力所の『かかりつけ薬局』に統一している」の 3 肢として, 最後を選択したグループを「かかりつ け薬局群」と見なすことにした。

2. データの取り扱い 今回の調査では, 調査 方法 2 の通り，回答者に特定企業の社員・家族が含 まれた点に注意する必要がある，同企業は傘下に医 薬品部門を持つため，この部門の回答者は，薬局薬 剂師に対して好意的な回答をする可能性等が考えら れた。 そのため, 調査に際しては, あらかじめ医薬 品部門の社員・家族を対象から除外した。しかし, 他部門の社員・家族であっても同様の回答をする可
能性はある.

そこで, 調査方法 1（薬局店頭で患者に調査票を 配付）と同 2 (企業の社員・家族に調查票を配付) について，別々に集計を行った，その結果，Table 2 の通り, 調査方法 1 の方が同 2 よりも「かかりつ け薬局群」の人数比は高かった。 また, Table 3 の 通り, 調査方法 1 の回答者の方が，同 2 よりも，む しろ薬局薬剤師に好意的な回答をしていた。これら より, 調查方法 2 の回答者が特定企業の社員・家族 であることを理由に，薬局薬剤師に好意的な回答を したとは考えにくい.

ほかにも検討を要する問題はある。しかし，今回 は「かかりつけ薬局」を持つ患者と持たない患者に ついて，視点や意識の違いを見ることを目的とした ので, 調査方法 1 と同 2 の回答を合わせて解析して も差し支えないと判断した。

3. 各群の特色 Table 1 において, 設問 $\mathrm{N}$ (薬剂師による「薬のチェック」や「薬の説明」の 作業に対してお金を払つてもいい) の加重平均值 は，どの群においても低值であった。この理由には 「お金を払わないですむならば，それにこしたこと はない」という消費者感覚．さらには，「チェック」 や「説明」という無形のものに対して，お金を払う ことへの抵抗感などが挙げられるであろう。また, 現状の薬局サービスに対する患者の厳しい評価が含 まれている可能性も否定できない.

しかし，設問 $\mathrm{N}$ も含めて，「かかりつけ薬局群」 が多くの設問で他群よりも高值を示した．本群の患 者は最も医薬分業の意義を認め, 薬局薬剤師の仕事 にも理解を示していることなどが観察される.

このように，Table 1 から設問ごとに 3 群間の違 いを見ることはできるが，しかし，各群の特色を明 確にすることは容易ではない。そこで，各群の因子 分析を行い，各設問がごのような潜在因子によって 影響を受けているのかを明らかにした。 その結果,

Table 4-6 の通り，第 2-4 因子の順番が各群間で 異なつたので，主にこれらに着目して考察を行つた。

3-1.「決めていない群」本群では, Table 4 の通り，「懐疑・不満」が第 2 因子となった。設問 G（医療関係者に，自分の要望を聞いてほしいと思 うことがある)，設問 $\mathrm{E}$ (医師の治療方針に対して, 疑問をもつことがある）などが，この因子と強い相 関を示したことから，本群の患者は自分の治療に関 
して十分納得していない状態と想像された.

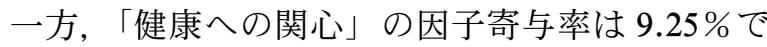
あり, 他群（病院・診療所ごと群 : 8.16\%, かかり つけ薬局群：7.85\%）よりも高值であったことか ら，本群の患者は健康に対してけっして無関心では ないと判断される。ささらに「薬局薬剤師への評価」 や「人や店への愛着心」の因子寄与率も，「かかり つけ薬局群」(Table 6) のそれらと大差はなかった. これより，今回の検討範囲では，本群の患者は「懐 疑・不満」が解消されれば，「かかりつけ薬局群」 に転じる可能性があると思われた。

3-2.「病院・診療所ごと群」印南ら4)によれ ば，患者は「交通の便」「接客態度」「必ず調剤して もらえること」などを重視して，薬局を選定してい るという。このような患者は，いわゆる門前薬局な ど，病院・診療所ごとに行く薬局を決めることが多 いであろう。そこで，本群の患者は利便性や快適性 を重視するタイプと考えた。

本群では, Table 5 の通り「薬局薬剤師への評価」 が第 2 因子となつた。この因子と強い相関を示した 設問 J（薬局薬剤師に親しみがもてる）や，設問 $\mathrm{K}$ （薬局薬剤師の仕事ぶりは評価できる）は，印南ら が指摘する利便性や快適性を享受して満足した結果 により,「あてはまる」と回答されたと解釈できる.

一方， Table 1 の中の 11 設問において，「かかり つけ薬局群」の加重平均值が最高值，2番目が「病 院・診療所ごと群」，3番目が「決めていない群」 の順となり， 3 群間で有意差が見られた。これらの 設問内容に注目すると，本群の患者は「決めていな い群」の患者に比べて，あたかも将来「かかりつけ 薬局」を持ちそうに見える.しかし，「かかりつけ 薬局」を持てば，本群の患者が重視している利便性 や快適性は多少損なわれる可能性がある，また，本 群では「人や店への愛着心」の因子寄与率は 3.09 \%であり（Table 5)，他群のそれよりも低值であっ た（決めていない群 : $5.43 \%$, かかりつけ薬局群 : 5.44\%)。これらより，今回の検討範囲では，本群 の患者は，かならずしも「かかりつけ薬局群」の予 備軍であるとは思われない.

\section{3-3.「かかりつけ薬局群」＼cjkstart本群では，Table 6} の通り「健康への関心」が第 2 因子となつた。設問 F（治療を受ける際，患者にはその内容について知 る権利がある）は，本因子と強い相関を示した。一
方，他の 2 群ではいずれも「懐疑・不満」と強い相 関を示している点が注目される．同じ「患者の知る 権利」であっても，本群と他群とでは患者の視点は 異なる。「懐疑・不満」が下位因子（第 4 因子）に なったことも合わせて，本群の患者は，既に自分の 治療に関してある程度納得していることが想像され た.

本群の患者が利用する薬局は，「病院・診療所ご と群」の患者が利用する薬局に比べて，利便性等は 低い可能性がある。したがって，「薬局薬剤師への 評価」（第 3 因子）と強い相関を示した各設問は, 「病院・診療所ごと群」の患者とは若干異なる視点 で回答されたと推測する，例えば，薬歴の一元化に よって可能となる相互作用や重複投薬の防止など, 他群では得られにくい面が評価に加わっていると考 える。

\section{おわりに}

患者の健康に対する関心，医療に対する考え方等 について調査を行ったところ，「かかりつけ薬局」 を持つ患者と持たない患者との間で，違いを見るこ とができた。これより，本研究の結果は，患者が 「かかりつけ薬局」を持つための対策を検討する上 で参考になると考える.

「かかりつけ薬局」を決めていない患者は，懐疑・ 不満が強いことが観察され，自分の治療に関して十 分納得していない状態であると考えられた。薬剤師 が患者の要望を引き出し，可能な対応を取ること. また，心配・不安の相談にのること等により「かか りつけ薬局」を持つことが期待できる.

病院・診療所ごとに利用する薬局を決めている患 者は，主に利便性を重視するタイプと思われた。 「かかりつけ薬局」の定着のためには，例えば薬歴 を一元化することで薬物治療の安全性を高めること が可能になること．さらには，大衆薬や特定保健用 食品等の使用に関しても，より的確なアドバイスを 受けられるようになること等を知ってもらう必要が あると考える。

しかし，患者が「かかりつけ薬局」を決めること には，ほかにも様々な要因があることだろう。例え ば患者とのコミュニケーションのあり方, ${ }^{7)}$ 個々の 薬局薬剤師の技能と態度, さらには保険上のルール により薬局での患者一部負担金に違いが生じている 
ことなども関係があるかもしれない，今後，幅広く 検討する必要がある.

謝辞因子分析の結果解釈について, 多くのご 助言をいただいた青山学院大学国際政治経済学研究 科の内山義英助教授に深謝いたします。

\section{REFERENCES}

1) Japan Self-Medication Industry, Report (2004). 〈http://www.jsmi.jp/reserch/isiki 28/28.pdf $\rangle$ JSMI Web, 24 September, 2005.

2) National Federation of Health Insurance So- cieties, Report (2002). 〈http://www.kenporen.com / tyousa / pdf / tyousa14_01.pdf $\rangle$ KENPOREN Web, 24 September, 2005.

3) Kasuya M., Kato Y., Li X., Tsuzuki K., Sekita Y., Health Sciences., 17, 55-65 (2001).

4) Journal of the Japan Pharmaceutical Association, 56, 529-544 (2004).

5) Kamei M., Shiragami M., Japanese Journal of Social Pharmacy, 23, 7-14 (2004) .

6) Journal of the Japan Pharmaceutical Association, 57, 5-9 (2005).

7) Saeki H., Medicine and Drug Journal, 41, 999 -1003 (2005). 